\title{
DEVELOPING INTERNATIONAL REFUGEE LAW IN THE ASIAN PACIFIC REGION: SOME ISSUES AND PROGNOSES
}

\author{
Patricia Hyndman* *
}

\section{INTRODUCTION}

"There are few human dramas more compelling, or more revealing of the troubled times in which we live, than the plight of millions of refugees around the glove. And there are few greater tests of the democratic and humanitarian ideals for which we stand than how we respond to the needs of the world's homeless." 1

It is estimated that there are over $15,000,000$ refugees in the world today. ${ }^{2}$ Of this $15,000,000$ approximately $6,000,000$ are to be found in South and South-East Asia. There are approximately 2,350,000 Afghan refugees in Iran, 3,580,000 Afghan refugees in Pakistan, and 560,000 Indo-Chinese refugees in camps in different countries in South-East Asia. ${ }^{3}$

Refugees are people in particular need of international protection. By definition they are outside their own country, and, owing to fear of persecution, are either unable or unwilling to turn to its authorities for assistance. In addition they may not have complied with the entry requirements of the country to which they have fled. By the very nature of their circumstances they generally will not have obtained the relevant visas, and, most probably, will not enter the territory of the state in ques-

\footnotetext{
* The text, parts of which have been published earlier elsewhere, is also included in the Report of Proceedings of a meeting of the Pacific Region and International Law Conference (PRIL), Melbourne, August 1990

** Associate Professor of Law, University of New South Wales, Sydney; Director, University of NSW Human Rights Centre; Secretary, LAWASIA Human Rights Committee.

1. Senator E. Kennedy, "Introduction" to 1980 World Refugee Survey (U.S. Committee for Refugees, New York), p.5.

2. 1989 World Refugee Statistics in World Refugee Survey-1989 In Review, p.31.

3. Ibid.
}

Ko Swan Sik et al. (eds.), Asian Yearbook of International Law, 19-44.

(c) 1993 Kluwer Academic Publishers. Printed in the Netherlands. 
tion at an authorised border point. They may not possess valid passports. As a consequence they frequently arrive in a new country illegally. Furthermore, the country in which they have arrived may, for various reasons, not welcome immigrants from the refugees' country of origin (for instance, they may be traditional enemies, as is the case with Cambodians seeking refuge in Thailand). Very often refugees may be stateless persons as well. Hence refugees are people generally in urgent need of assistance, yet there may be no State-authorities to which they are able to turn for help.

\section{THE 1951 CONVENTION}

Today the major international convention giving protection to refugees is the 1951 Convention Relating to the Status of Refugees ${ }^{4}$ as supplemented and made more relevant to modern conditions by its 1967 Protocol. ${ }^{5}$ As at early August 1990, 107 States were parties to either the Convention or to the Protocol, or to both instruments.

The 1951 Convention has three main functions. Firstly, it provides a general definition of the term "refugee", as contrasted with the early definitions which were related to specific events. Secondly, it contains the basic charter of rights afforded to persons who have been granted refugee status: it has been referred to as the Magna Carta for refugees. Thirdly, it contains provisions concerning the implementation of the Convention.

(i) The definition of "refugee"

Turning firstly to the general definition of "refugee", the Convention specifically provides that all those persons given refugee status under the earlier conventions are still be considered as refugees. ${ }^{6}$ In addition, a general definition is provided - a refugee is a person who,

"owing to well-founded fear of being persecuted for reasons of race, religion, nationality, membership of a particular social group or political opinion, is outside the country of his nationality and is unable or, owing to such fear, is unwilling to avail himself of the protection of that country; or who, not having a nationality and being outside the country of his former habitual residence is unable or owing to such fear, is unwilling to return to it..."?

\section{189 UNTS No. 2545.}

5. 606 UNTS No. 8791. The Protocol made certain provisions of the Convention more suitable to changed circumstances. Although most signatory States have acceded to both instruments, accession to the Protocol alone carries with it accession to most of the Convention Articles.

6. Article $1 \mathrm{~A}(1)$. 
It will be noted that several requirements must be met in order for a person to come within this definition. One is that the refugee must be "outside" his or her country of nationality of habitual residence. Many people may find themselves in refugee-like situations, and may have fled considerable distances, but if no border has been crossed they will not be considered to be refugees. An example of people in this situation would be the many displaced people in Vietnam during the 1970s. As long as a person is outside his or her country of nationality or habitual residence, it is not necessary that the departure was originally made for fear of persecution. It is possible to be already out of a country when the situation changes, and then, because of the changed circumstances to have a wellfounded fear of persecution should a return be made to the country.

Another element in the definition is the requirement that the refugee must have a well-founded fear of "persecution". There is no generally accepted definition of persecution. This term would certainly cover loss of life or imprisonment for one of the reasons specified in the definition. To go beyond this is to enter an area of controversy. Clearly a person is not a refugee if that person is outside his or her own country simply because he or she is able to earn a better living in the new country. However, the definition may include the economic persecution of a particular class if this is done for the reason that the persons are members of that class. The persecution feared from the country of origin must be due to one, or a combination of, the causes specified in the definition - that is for reasons of race, religion, nationality, membership of a particular social group or political opinion.

In addition the fear in question must be well-founded. The decision as to whether there is a "well-founded fear" of persecution has both the subjective and an objective element. ${ }^{8}$ The decision-maker must be satisfied that the person in question subjectively has a real fear. One person may have genuine fear when another, in similar circumstances, would not be so affected. Further, from an objective standpoint, it must be reasonable to have such fear.

Granting refugee status can be a delicate political matter. It can be seen as involving a comment upon the internal affairs of the country from which the person has fled and to amount, in effect, to a statement that

7. Article 1A(2) of the 1951 Convention as amended by Article 1(2) of the 1967 Protocol, hereinafter referred to as the Convention definition.

8. A recent decision of the Full Court of the High Court of Australia, Chan v Minister for Immigration, $63 \mathrm{ALJ}$ (1989) p.561, has altered the trend of recommendations of the Australian Determination of Refugee Status (DORS) Committee which prior to Chan had been to give an unduly restrictive interpretation to this phrase. See J. Crawford and P. Hyndman, "Three heresies in the application of the Refugee Convention", 1 JRL (1989) 155, and P. Hyndman, "Comment on Chan", 1 JRL (1990). 
there may be reasons why people within the country fled could fear persecution on the grounds of race, religion, nationality, membership of a particular social group or political opinion. Because of the negative imputation which this carries, and the possible detrimental effect upon the relationship existing between the country of refuge and that of origin, many States, for considerations of a purely political nature, hesitate to grant refugee status to people who in fact quite clearly fall within the Convention definition. It has been said, for example, that this is why certain groups of applicants in the United States, Haitians for example, have experienced difficulties with their applications for refugee status made there. ${ }^{9}$ Another consideration which can affect refugee status decisions is the apprehension that if this status is granted to an applicant of a particular nationality this may encourage, in anticipation of a favourable response, waves of asylum-seekers from the same country of origin to arrive at the borders of the receiving State. This may well be the reason why very few applicants from Sri Lanka have succeeded in applications for refugee status made in Australia.

The definition contained within the 1951 Convention, linked as is to specific causes, obviously does not cover everyone outside his or her country, in a situation of distress, and unable to return home. People may be unable or unwilling to return to their own country due to circumstances such as natural disasters - famines, floods or earthquakes or to man-made circumstances such as local civil disturbances and the consequent breakdown of food supplies medical assistance, transport facilities and normal civilian life. These circumstances, however, are not included within the criteria specified in the Convention definition and, without more, people in these situations will not qualify as Convention refugees

The 1951 Refugee Convention was drawn up primarily to deal with the situation of displaced people in Europe immediately after the Second World War, and to provide protection for those people. The States ratifying the Convention were anxious to make their obligations specific and to ensure that those obligations could not be extended indefinitely. Today, circumstances have changed and many people who need international protection of the kind provided by the Convention do not fall within the ambit of its definition. This can be graphically illustrated by examples from the Asian Pacific region. Hundreds of thousands have fled from Sri Lanka to escape the civil strife and the consequent disruption to normal life, thousands more are displaced within the country, many having fled from their homes in the north and east due to increased violence. People

9. See J. TenHULA, "Boat people flee Haiti to U.S.", 1980 World Refugee Survey (U.S. Committee for Refugees, New York) p.52-54. For political reasons other applicants also, for instance El Salvadoreans, experience difficulties in establishing they are refugees. 
have arrived in Australia by boat fleeing the fighting in Cambodia, not to mention of course the untold number who have left Vietnam over the last 15 years. Not all of these people would fit into the Convention definition, and many are described as economic refugees - a description easy to attach but not always easy to clearly separate from the Convention definition requirements.

Interestingly the UN Office of the High Commission for Refugees (UNHCR) has been able to extend its protection to groups which would, or may, not technically fall within either the 1951 Convention or the UNHCR Statute definition of refugee, and to persons whose refugee status has not been determined. This has been done through the utilisation of the reference in the Statute definite to "groups of refugees" and through expansion under the "good offices" function of UNHCR. By these means the UN General Assembly has effectively extended the mandate of the High Commissioner, from time to time requesting him to extend his good offices to specific groups of people who may not otherwise fall within the mandate of the Office.

An example of this occurred in the 1950s when the High Commissioner was requested to use his good offices to assist people from mainland China who were now in Hong Kong. ${ }^{10}$ UNHCR did render assistance even though, technically, many of these people may not have been refugees, since they may have been able to rely upon the protection of either of two different countries. The good offices function has been utilised also in situations of mass influx when it has been impossible, because of the numbers involved, for questions of refugee status to be determined.

In addition to situations of the kinds outlined above, UNCHR has been asked to assist in repatriation programmes. In the early 1970 s ten million people left what is now Bangladesh and fled to India. They returned to their homes under agreements made between the Bangladesh and Indian governments. UNHCR, requested to do this by the United Nations, ${ }^{11}$ assisted in that return. Once back within the borders of their own country the people from Bangladesh were no longer outside their country and therefore were no longer refugees. Nonetheless the Office of UNHCR was authorised to provide assistance to them and, since that time, UNHCR has assisted in many repatriation programmes, particularly on the continent of Africa. Recently UNHCR has been involved in the repatriation of some Laotians to Laos from Thailand, and, after the July 1987 Peace Accord, of Sri Lankan Tamils from India back to Sri Lanka. ${ }^{12}$ There has been an exten-

10. UNGA Res. 1167 (XII) of 26 Nov. 1957. Another instance is UNGA Res. 167 (XVI) of 10 Dec. 1961, authorising assistance to Angolan refugees in the Congo.

11. UNGA res. 1790 (XXIV). 
sive repatriation programme to Namibia and there is the new and controversial programme of return to Vietnam.

A point which needs to be emphasised in relation to the Convention definition of refugee is that its wording is in terms of individuals. An individual determination is required in each case before a State decides whether or not to grant refugee status. Obviously, the making of a determination is not always either practical or even possible, particularly in circumstances of mass exodus, where hundreds of thousands of people can pour across a border in a matter of days. Also, even without vast numbers, an individual determination may simply not be feasible because the country concerned may not possess administrative procedures that are capable of performing such a function.

There is no obligation under the Convention to set up procedures for the determination of refugee status, and many countries have not done this. Where such procedures have been established they vary widely. UNHCR does endeavour to encourage uniformity and a standard practice, but, due to the differences in the administrative structures and general circumstances of different States, this is not easy.

If a person is declared to have the status of refugee, and if the State granting that status is a party to the 1951 Convention and/or 1967 Proto$\mathrm{col}$, then the refugee will fall under the protection of the Convention. It should be noted here that a person may qualify for UNHCR protection and fall within the mandate of UNHCR even though he or she is not in a country which is a party to the Convention.

(ii) Rights conferred upon refugees by the 1951 Convention and/or 1967 Protocol

The 1951 Convention contains a comprehensive charter of rights which signatory States agree to confer on refugees. Strictly speaking the use of the word rights here is not correct. It is used as a matter of convenience. States, not individuals, are the traditional subjects of international law and generally individuals do not have the capacity to enforce their rights before international tribunals. Consequently, although the rights and duties of refugees are often mentioned, a more accurate description would be the rights declared on behalf of refugees.

12. For an account of this programme, see UNHCR, Refugees Magazine, No.63, April 1989, pp.19.33; and for a critical assessment of its desirability see Repatriation of Tamil Asylum Seekers; Journey into Peril, (Report No.1, Tamil Refugee Action Group, London, 1989). For a survey of the circumstances in Sri Lanka which haveled to the existence of large numbers of Tamil refugees, see P. Hyndman, Sri Lanka: Serendipity under Siege (Bertrand Russell Press, Nottingham, 1988); and for a study of the application to them of the 1951 Refugee Conventions, see P. Hyndman, "The 1951 Convention definition of refugee: An appraisal with particular reference to the case of Sri Lankan Tamil applicants," HRQ (1987), pp.49-73. 
The rights declared in the 1951 Convention include rights such as the following: freedom of association and movement; the right to acquire movable and immovable property; rights in literary, artistic and scientific works; protection of industrial property; the right of recognition of qualifications; provisions regarding welfare; housing; public education; transfer of assets; the right to freedom of religion; to naturalisation; to access to courts; to identity and travel documents, and the right to engage in selfemployment or wage-earning employment. ${ }^{13}$

There are differing levels at which these rights are required to be conferred. In some cases the rights must be granted in a manner such that the situation for the refugee is at least favourable as the conditions granted to other aliens. In other cases ${ }^{14}$ refugees are required to be given the most favourable treatment accorded to the national of another country. ${ }^{15}$ In yet others the same treatment is required as that accorded to the national of the country of refuge. ${ }^{16}$

(iii) Implementation provisions

The third major section of the 1951 Convention contains implementation provisions. All contracting parties agree to cooperate with UNHCR, in particular facilitating its duty of supervising the application of the Convention. They also undertake to submit to the United Nations reports providing information concerning refugees. ${ }^{17}$

\section{POSSIBLE PERMANENT SOLUTIONS}

Despite the provisions outlined above, and despite the fact that in this century considerable progress has been made towards the establishment of an international system for the protection of refugees, there are, as noted above, nonetheless, an estimated 15,000,000 refugees in the world. There are various possible permanent solutions to the problems which face these people.

The fist, and most preferred by UNHCR, is voluntary (not forcible) repatriation. This is considered to be the most desirable, and the least disruptive and expensive, solution both for the refugees themselves and for the rest of the world community. As mentioned earlier, in South-East Asia there have been some cases of voluntary repatriation of refugees

13. See Articles 3-34, 1951 Convention.

14. E.g. Articles 7, 13.

15. E.g. Article 15.

16. E.g. Articles 4, 14.

17. Articles 35 and 36,1951 Convention. 
from Thailand to Laos, of Vietnamese to Vietnam, and in South Asia UNHCR has encouraged a repatriation programme for Sri Lankan Tamils who had fled to India. However, in some cases repatriation is simply not possible. This may be for the reason, for example, that the situation from which the refugees have fled shows no sign of improvement.

The second most desirable solution is generally considered to be the absorption of the refugees into neighbouring countries where it is likely, although nor necessarily the case, that there will be similarities in such matters as culture, economic conditions, ethnic composition of the population, climate and language. However, such assimilation is not always either easy or possible. The poverty of the countries in question and the cost to them that assimilation would entail may make this solution very difficult indeed. In addition there may be other difficulties. In the case of Malaysia the problems posed by the arrival of thousands of Indo-Chinese refugees is not just one of finding them accommodation, food and employment. Malaysia is a country which has a delicate balance of races. An influx of large numbers of one of the races already present there could upset the ethnic balance and cause internal problems within the host country.

Resettlement in other countries is the third solution. This is considered to be a solution of last resort because it is disruptive, both to the refugee and to the country of resettlement, and it poses many problems of assimilation which can cause immense difficulties. The international community has responded to the problems facing refugees, and facing the countries to which they have fled, by offers of resettlement in distant lands. For instance Indo-Chinese refugees have been resettled in such diverse locations as Australia, Canada, France, New Zealand, Switzerland, the United States of America, in Caribbean and in Scandinavian States, and in some countries within the South Pacific region. Nevertheless, many refugees still remain in the countries of first arrival. In the Asian region as mentioned already there are thousands of Indo-Chinese refugees currently in camps in Hong Kong, Indonesia, Malaysia, the Philippines and Thailand. In Pakistan there are 3,500,000 refugees from Afghanistan.

\section{ASIA AND THE LAW CONCERNING REFUGEES}

Despite the fact that currently there are 107 States parties to the 1951 Convention and/or its 1967 Protocol, many countries which do harbour large numbers of refugees, and are vitally concerned with refugee problems are not parties to the refugee conventions. In the cases of the coun- 
tries mentioned immediately above not one is a signatory. Indeed the States of the Asian region lag significantly behind those of the other regions of the world (with the exception of the countries until recently considered part of the Eastern bloc) in terms of accession to the refugee conventions. So far in Asia only China, Iran, Japan and the Philippines (and Iran, Israel and Yemen) are States parties. In the Pacific Fiji, Tonga, Western Samoa and Tuvalu are parties. Whereas States in other regions of the world have adopted binding regional instruments for the protection of refugees, there is no such instrument to protect the refugees of the Asian region.

The Principles Concerning Treatment of Refugees, ${ }^{18}$ however, should be noted here. These Principles, which are not binding, were adopted by the Afro-Asian Legal Consultative Committee in Bangkok in 1966. They provide for the definition and status of a refugee and loss of that status. These provisions are similar to the corresponding ones in the 1951 Convention except that the definition in the Bangkok Principles contains no dateline, and "colour" is included as an additional reason which may give rise to fear of persecution. Article IV States that a refugee has a right to return to the country of his or her nationality, and that country has a duty to receive the refugee. Article $V$ contains an interesting provision for a right to compensation from the country left by the refugee and to which he or she is unable to return. Article VI accords to refugees "treatment in no way less favourable than that generally accorded to aliens in similar circumstances" and Article VII proves that refugees

"shall not engage in subversive activities endangering the national security of the country of refuge, or in activities inconsistent with or against the principles and purposes of the United Nations."

There are also provisions relating to expulsion, deportation and asylum, and a final Article preserves any higher rights granted to refugees under other arrangements.

In summary, the situation within the Asian Pacific region is that very few States have acceded to treaties, and thus very few States have expressly undertaken any binding obligations to afford specific protection to refugees. Although regional principles the treatment of refugees have been agreed upon they are not binding. Clearly then, whatever the

18. UNHCR, Collection of International Instruments concerning Refugees (2nd ed., 1979), p.201. The function of the Committee under its Statute was advisory only, and the view was taken that it would be up to the government of each participating State to decide how it would give effect to the recommendations. For a further discussion of these Principles, see E. JAHN, "The Work of the Asian African Legal Consultative Committee on the Legal Status of Refugees." 27 ZaöRV (1967), p. 122; and E. JAIN, "Developments in Refugee Law in the Framework of Regional Organisations Outside Europe", 4 AWR (1966), p. 77 et pp. 79,80. 
obligations of admission laid down in the various international instruments, most Asian States are not bound by them as a consequence of any specific treaty commitments.

\section{THE CONCEPTS OF ASYLUM AND NON-REFOULEMENT}

Different reasons are given for the reluctance of some nations to accede to the major international refugee instruments. Undoubtedly one of the most important is the fear (held by many States) that, should they accede they will be bound to accept, and offer a permanent home to, all refugees arriving at their borders. In other words that they will be undertaking obligations to grant permanent asylum to the refugees. This apprehension is due to a misunderstanding of the provisions of the international refugee instruments.

The term asylum has no universally accepted definition. Here, it is used in the sense of admission to the territory of a State, and a distinction is made between admission which is granted as an emergency measure, guaranteeing refuge of a temporary nature only, and admission which encompasses the more durable aspect involved in the grant of a permanent right to settle.

There is no right to asylum (in either of these senses) granted, in so many words, to refugees by international treaties. In fact the 1951 Convention, in the main body of its text, makes no reference to asylum at all, although there is mention of it in the Preamble and in the Final Act. Even there the mention is not made in terms which impose any obligation upon signatory States to grant asylum to refugees. The 1967 Protocol carries the situation no further.

However, there are other provisions of the 1951 Convention which do have a bearing on the problem of admission. These are Articles 31, 32 and 33. Article 31 stipulates that, even if refugees have entered a country illegally, contracting States shall not impose penalties upon them on account of their illegal entry or presence, and Article 32 States that refugees who are lawfully within the territory of a contracting State shall not be expelled by that State save on grounds of national security or public order. If any expulsion does take place, under this provision it must be carried out in pursuance of a decision reached in accordance with due process of law, and allowance should be made for a reasonable period to elapse during which the refugee might seek lawful admission to another country. Article 33 (the non-refoulement provision) states that:

"no Contracting State shall expel or return (refouler) a refugee in any man-

ner whatsoever to the frontiers of territories where his life or freedom 
would be threatened on account of his race, religion, nationality, membership of a particular social group or political opinion."

Whereas Article 32 requires persons to be lawfully within the state before its provisions will apply, there is no such restriction in Article 33 which applies to protect refugees even though they may be in a country illegally.

Although none of these Articles gives to refugees a right to enter another country, their conjunction does provide some real protection, For, although an administrative act of ordering the expulsion of a refugee may not offend against Article 32, actual expulsion may be forbidden under Article 33 if it will result in the return of the refugee to a country where he or she fears persecution.

Other international instruments exist in which it may reasonably be expected that some provision granting a right of asylum to refugees might be found. However, on examination, it will be seen that none of these, not even the 1967 UN Declaration on Territorial Asylum, ${ }^{20}$ actually goes so far as to impose an obligation on States to grant asylum to refugees arriving at their borders. States the world over consistently have exhibited great reluctance to relinquish their sovereign right to decide which persons will, and which will not, be admitted to their territory and given a right to settle there. They have refused to agree to international instruments which would impose on them duties to make grants of asylum. ${ }^{21}$

The provisions of the Bangkok Principles Concerning Treatment of Refugees which are relevant in this context are as follows. Article III provides that:

1. A State has the sovereign right to grant or refuse asylum in its territory to a refugee.

2. The exercise of the right to grant such asylum to a refugee shall be respected by all other States and shall not be regarded as an unfriendly act.

3. No-one seeking asylum in accordance with these Principles should, except for overriding reasons of national security or safeguarding the populations, be subjected to measures such as rejection at the frontier, return or expulsion which would result in compelling him to return to or remain in a territory if there is a well-founded fear of persecution endangering his life, physical integrity or liberty in that territory.

19. Refugee (Germany) Case, 28 I.L.R., p.297 at p.298; Chim Ming v. Marks, (1974) 505 Fed. $2 d .1170$ at p.1172. The ambit of the non-refoulement requirements of Article 33 is dealt with in more detail in P. Hyndman, "Asylum and Non-Refoulement: Are these Obligations owed to Refugees under International Law?", 57 Philippine L.J. (1982), pp.43-77.

20. Adopted by UNGA Res. 2312(XXII), 14 Dec. 1967.

21. For a comprehensive description of the attempts to reach agreement on a Convention on Territorial Asylum, see A. Grahl-Madsen, Territorial Asylum (Oceana, London, 1980). 
4. In cases where a State decides to apply any of the above-mentioned measures to a person seeking asylum, it should grant provisional asylum under such conditions it may deem appropriate, to enable the person thus endangered to seek asylum in another country.

As can be seen, the decision as to whether or not a grant of asylum should be made to one person, or to a group of persons, is still left within the sovereign discretion of the State concerned. However, unlike the wording of Article 33 of the 1951 Convention, here non-rejection at the frontier is specifically included within the non-refoulement provision, and article III.4 adverts to a requirement of a grant of temporary asylum in certain circumstances.

The provisions of the Principles regarding expulsion are contained in Article VIII and are as follows:

1. Save in the national or public interest or on the ground of violation of the conditions of asylum, the State shall not expel a refugee.

2. Before expelling a refugee, the State shall allow him a reasonable period within which to seek admission into another State. The State shall, however, have the right to apply during the period such internal measures as it may deem necessary.

3. A refugee shall not be deported or returned to a State or Country where his life or liberty would be threatened for reasons of race, colour, religion, political belief or membership of a particular social group.

Though an exception is allowed in Article VIII.1 on the grounds of "national or public interest", Article VIII.3 allows no such exception, and is more stringent than Article 33 of the 1951 Convention, containing as it does an absolute prohibition of the refoulement of a refugee. However, as noted already, these Principles are not binding.

Today, the generally accepted position internationally would appear to be this - States consistently refuse to accept binding obligations to grant to persons who are not their nationals any rights to asylum in the sense of a permanent right to settle there. Apart from any limitations which might be imposed by specific treaties, States have been adamant in maintaining that the question of whether or not a right of entry should be afforded to an individual, or to a group of individuals, is something which falls to each nation to resolve for itself. 22

22. S. PrakASH Sinha, Asylum and International Law (Martinus Nijhoff, The Hague, 1971), p.108. (However, it should be noted that on the municipal plane States have been willing to assume obligations which they have so far been loath to undertake on the international level, A. GraHl-Madsen, Territorial Asylum, op.cit., p.24). States' continued adherence to this position was made clear at the two recent meetings held to discuss the current situation of the people who are continuing to leave Vietnam (the first in Kuala Lumpur, held March 8, 1989, the second in Geneva, held 13 and 14 June, 1989). For the Draft Declaration and Comprehensive Plan of Action approved by the March 1989 Kuala Lumpur meeting and adopted at the June 1989 Geneva meeting, see UN Doc.A/Conf. 148/2. 
This is not only the case where international instruments are concerned. It is also the position under customary intemational law. If obligations can be shown to exist under customary international law, those obligations will bind all nations regardless of whether there has been any explicit undertaking through accession to a treaty. In order for an obligation to become a recognised part of customary international law, there must be exhibited both a consistency of State practice and a belief on the part of those observing the practice that this observation is mandatory. 23

Regarding non-refoulement also it must be acknowledged that actual and threatened behaviour of governments, i.e. State practice, does not always accord with the recognition of the existence of an obligation of non-refoulement. The point must of course be made that actual incidents of refoulement are unusual and are out-weighted by the innumerable occasions on which the principle of non-refoulement is scrupulously observed. A striking example is the acceptance and accommodation over several years, with no suggestion of return, of the 3,500,000 Afghans who have found refuge within Pakistan. Overwhelming and seemingly impossible numbers of refugees are constantly given shelter by host countries on the African continent. ${ }^{24}$ However, though instances of refoulement are exceptional their occurrence unfortunately is undeniable. For instance Thailand sent back to Cambodia some 40,000 Cambodians in mid-1979 25 and in mid-1987 sent back Laotians to Laos. During recent months there has been increasing talk by recipient countries, particularly by Hong Kong, of forcible repatriation to Vietnam. ${ }^{26}$ (There are of course very recent examples within the region of States pushing boat people out to sea. Thailand did this in $1988^{27}$ and in 1989 Malaysia followed - pushing thousands off its coasts. Such incidents, though in some cases more dangerous for those involved than actual refoulement (it would be impossible to estimate how many deaths have been caused by push-offs) are not instances of refoulement. Refoulement is the sending back of a refugee to the terri-

23. North Sea Continental Shelf Cases, (1969) I.C.J. Rep. p.3, at p.44.

24. See generally on the situation of refugees in Africa: Report of the Conference on the Situation of Refugees in Africa, May 1979 (UN Doc A/AC.96/INF. 158) and G. MELANDER \& P. NOBEL. (eds.). African Refugees and the Law (Scandinavian Institute of African Studies, Uppsala, 1978).

25. UN Doc A/34/627 Annex 1,p.3.

26. See, e.g.,statement by Countries of Temporary Refugee Meeting in Manila, 16 May 1990, reported in UNCHR Report of the Informal Meeting of the Steering Committee of the International Conference on Indo-Chinese Refugees, Manila, 17-18 May, 1990, p.1. Forcible repatriation of people validly determined not to be refugees is not refoulement as that principle protects only refugees.

27. For a comprehensive account of the situation of refugees in Thailand, see A. HELTON, “Asylum and Refugee Protection in Thailand, "1 IJRL (1989), pp.20-4. 
tory of a State where he or she has a well-founded fear of persecution, push-offs do not have this consequence.)

In order to establish the existence of a rule of customary international law not only must State practice be shown to be "both extensive and virtually uniform" (including the practice "of States whose interests are specially affected") it must also be shown that there is "a general recognition that a rule of law or legal obligation is involved" ${ }^{28}$ That is, a belief on the part of States in the binding nature of the practice in question is necessary.

In relation to this latter point it must be noted that several South-East Asian nations have made repeated assertions that they have no legal obligations to the refugees arriving at or crossing their borders, making the point that admission, where given, has been granted as a humanitarian gesture only, and not as a result of any duty owed under customary international law. ${ }^{29}$ On several occasions these States have stressed that in the future admission will continue to be granted only if assurances are forthcoming to the effect that the international community will guarantee that those nations granting initial asylum will be left with no resultant longterm burdens. They have stressed also that where the refugees are unable to return to their homelands they must be given resettlement opportunities elsewhere. The government of Hong Kong has taken a very firm stand in relation to the record numbers of people arriving in the colony from Vietnam, and has clearly stated that alone it will continue to provide shelter only for those determined to be Convention refugees. In June 1988 the Hong Kong authorities introduced a new screening process to determine whether or not the boat people arriving in Vietnam after that date qualify for refugee status. According to reports by observers fro independent non-governmental organisations such as Amnesty International and US based Lawyers Committee for Human Rights this screening procedure proved to be unfair and improperly restrictive. ${ }^{30}$ As will be covered in more detail later, in mid-1989 UNHCR embarked on a large hiring and training programme, and the screening process has been reported much

28. North Sea Continental Shelf Cases, (1969) I.C.J. Rep. 3 at 43.

29. See, e.g., speech by Malaysian Minister of Foreign Affairs, 12th ASEAN Foreign Ministers Meeting, Bali, Indonesia, June 29-30, 12 Foreign Affairs Malaysia (1979), p. 176, $177,195$.

30. "From June 1988 through March 1989 only 3 out of 1,327 Vietnamese cases processed have been recognised as meeting refugee status requirements under international law... Screening is conducted with improper criteria that, for example, do not consider current country conditions or past treatment ... Although UNHCR representatives have served as observers they have been unable to ensure a reliable procedure, both because of UNHCR delay in establishing an adequate monitoring and protection presence and the intransigience of Hong Kong authorities". Inhumane Deterrence: The Treatment of Vietnamese Boat People in Hong Kong, (Lawyers Committee for Human Rights, New York, 1989), p.5. See also pp.36-45, 49-56. To March 1989 only a very small number (less than $1 \%$ of arrivals) of those screened were determined to be refugees. Ibid. pp.4,5. 
improved. Nonetheless independent observers and NGOs continue to voice their concern that genuine refugees may be screened out - a very real danger if the consequence is to be forcible repatriation to Vietnam.

As well as stating that no legal obligations are owed to refugees arriving at or crossing their borders, on many occasions South-East Asian governments have been careful to employ terminology which ignores the fact that the people seeking refuge may be Convention definition refugees. They have applied to them instead terms such as "illegal immigrants" "displaced persons", "economic migrants" ${ }^{n 2}$, "boat people" and even "tourists of the unwanted kind"33 but not "refugees". However, this, in itself, is not an argument against the existence of customary refugee law, in fact it can be an argument for its existence. It is an indication that "refugees" may be entitled to a definite standard of treatment under customary international law, even from nations under no treaty commitments, that the States which are often careful to avoid use of the term "refugee" do recognise this, and that the are endeavouring to avoid incurring these obligations by refusing to categorise the persons requesting their assistance as refugees.

In summary, the approach so far taken by States indicates that State practice and opinio juris has not yet given rise to any customary international law obligation to grant asylum. ${ }^{34}$ On the other hand, despite the general impression which may have been suggested by the preceding observations, a convincing argument can be made for the proposition that non-refoulement has now become a rule of general customary international law (the State practice and opinio juris which can be cited in favour of this far outweighing that against) ${ }^{35}$ although it has to be acknowledged that there is some dispute here, both as to the existence of any binding rule, ${ }^{36}$ and as to its exact ambit. ${ }^{37}$

31. The Washington Post, 10 April 1988, at A 26.

32. Press Release No. 3/2531, 25 April 1988, Permanent Mission of Thailand to the United Nations at 4, cited in A. Helton loc.cit. N.27, 3.36, In.100.

33. See, e.g., 12 Foreign Affairs Malaysia (1979), p.170,178,183.

34. For a list of authorities dealing with this whole question at international law, see P. HyND MAN, "An appraisal of the development of protection afforded to Refugees under international law", 1 Lawasia, N.S. (1981), p.229 at p.259, fn.73. The same principle has also been accepted in domestic courts, e.g. Nishimura Ekiu $v$ U.S., (1891) 142 U.S., p.651; Musgrove $v$ Chun Teeong Toy [1981] A.C., p. 272.

35. See, e.g., C.S. Goodwin-Gill, International Law and the Movement of Persons between States, (Clarendon Press, Oxford, 1978), p.141; G. JAEGER, op.cit., p.38.

36. A. Granil-Madsen, Territorial Asylum, op.cit., pp.42, 43; S. PraKash SINHA, op.cit., pp.159,280.

37. P. Hyndman, Asylum and Non-Refoulement, 57 Philippine L.J. (1982), p.43 at pp.49-52, 59-71. 


\section{A DIFFERENT APPROACH}

The traditional way of approaching this area of international law has been through these recognised legal concepts of asylum and non-refoulement. It is possible, however, to make the approach in another way.

If, for a moment the accepted legal concepts are ignored, and an inquiry is made simply as to the actual practice of States when faced with refugees at their borders, the current situation can be described in the following manner.

States insist that they will undertake no binding obligations to grant rights of permanent settlement to persons arriving at their borders, and that each nation has the sovereign right to determine for itself which persons are acceptable for such admission. Nevertheless, State practice does seem to indicate that, although some countries, particularly those within the South-East Asian region, are not prepared to admit a mass influx of refugees when they fear that they will be left to handle alone the costs and problems which such arrival must inevitably entail, they are prepared to admit these people, and to do their best for them if they have assurances that they will receive assistance from other States. For instance, although in June 1979 the government of Thailand sent back half of the 80,000 Cambodians who had crossed its borders in the first months of that year, in October, assured of international cooperation, it announced "that all the Kampuchean refugees would be granted temporary refuge in Thailand" ${ }^{38}$ This was a considerable undertaking since some 130,000 Cambodians were at that time in the border areas and another 200,000 had just entered Thailand. ${ }^{39}$ Furthermore, it was anticipated that the numbers would continue to increase. The present crisis regarding Vietnamese (and Cambodian) boat people may well be averted even now if clear assurances, of the kind outlined in the paragraph below, were to be provided.

The assistance required by these States of first asylum is twofold: firstly, to resolve the immediate difficulties and expenses; secondly, to provide assurances that, if temporary refuge ${ }^{40}$ is accorded, the international community, not the State of first asylum, will assume the responsibility for the permanent resolution of the situation in question - i.e. that there will be real and effective international cooperation and burdensharing. ${ }^{41}$

38. UN Doc. A/34/627, p.14.

39. Ibid.

40. On this concept, see G.C.L. Coles. Temporary Refuge and the Large Scale Influx, paper submitted to UNHCR-convened group, Canberra, March 1981. See also UN Doc. A/AC.96/599. 
Although governments so far have been reluctant to agree in principle to a scheme consisting of these dual obligations - a grant of temporary refuge coupled with an international assumption of responsibility for the resultant burden - and although States generally prefer to maintain that the country of first asylum has the full responsibility for any refugees on its territory, nevertheless, despite such pronouncements, the actual practice of States does indicate that both concepts do receive some acceptance in fact. This continued to be true even amid the hard-line approaches taken at the two 1989 international conferences convened (by the ASEAN governments in Kuala Lumpur in March and by the UN in Geneva in mid-June) to discuss the situation of escalating numbers of Indo-Chinese leaving Vietnam and the threats (since carried out in relation to 51 Vietnamese), particularly by Hong Kong, of the forcible repatriation $^{42}$ of those deemed not to satisfy the criteria for refugee status. At the May 1990 informal meeting of the steering committee of the international conference on Indo-Chinese refugees, despite the difficulties being faced by a number of first asylum countries and their emphasis on the need for agreement on the return of non-refugees, it was emphasised also that abandonment of first asylum could not be justified. ${ }^{43}$

Both temporary refuge and international burden-sharing are concepts already recognised in provisions within existing international instruments ${ }^{44}$ and, at different stages, various cooperative schemes have been set up to provide practical international assistance in line with their dictates. For instance boat people rescued by passing ships and taken to ports within the South-East Asian region have been granted permission to disembark and afforded temporary refuge by States formerly adamant in their refusal to allow this, once those States were assured of, and confident about, an international assumption of responsibility. Often States have stressed that they will only give permission for boat people to disembark if they have assurances of international burden-sharing. ${ }^{45}$ Differing schemes have been set up to provide these assurances and the very fact that such projects have been possible has indicated acceptance by

41. See, e.g., speech by Malaysian Minister of Foreign Affairs, loc.cit. n.32, at pp.186, 230, 274, 398; ASEAN Joint Communique, June 26, 1980, 13 Foreign Affairs Malaysia (1980), pp.199, 257264.

42. See, e.g., UN Doc. A/Conf. 148/2, paras 5,8,9,10,11.

43. See P. 2 of the UNCHR report of that meeting.

44. For example: Preamble and articles 31 and 32, 1951 Convention: Articles 2.2 and 3.3 UN Declaration on Territorial Asylum: Articles 11.4 and 11.5 OAU Convention, UNTS No. 14691; Council of Europe Resolution 14 (1967) on Asylum to Persons in Danger of Persecution, adopted by the Committee of Ministers on 19 June 1967.

45. D. WILLDAY, Resettlement of Indo-Chinese Refugees and Displaced Persons, UNHCR Doc. 155/ $49 / 80$, at pp.2,3,4; 12 Foreign Affairs Malaysia, (1979), pp. 185, 186, 230, 274 (1979); 13 Foreign Affairs Malaysia (1980), p. a199. 
States of the need for an assumption of the responsibility for refugees to be undertaken at an international level - that is, that there is recognition that the States nearest to the scene of the problems must not be left to cope with them alone. ${ }^{46}$

From time to time international appeals have been made for States to provide opportunities of permanent resettlement for people who can have no realistic expectation of being able to return to their own country in the near future. As an example, during and after a UN convened meeting held in Geneva in July 1979 to find solutions to the problems of the rapidly increasing numbers of Indo-Chinese refugees and displaced persons within the South-East Asian region, many offers of permanent resettlement opportunities were made. In several instances offers were made by States which had never made such opportunities available to refugees before. Resettlement offers which had numbered 125,000 in May 1979 had increased to over 260,000 by the end of the meeting. ${ }^{47}$ As a result of these offers the number of refugees awaiting resettlement in camps in Hong Kong, Indonesia, Malaysia and the Philippines, declined steadily immediately after the meeting. ${ }^{48}$ Again such action provides recognition of the need for international burden-sharing.

46. One such cooperative scheme was the establishment by UNHCR of a fund of resettlement offers guaranteed by participating States. The fund had the purpose of facilitating disembarkation from ships flying flags of convenience or flags of countries unable to provide settlement: see, UN Docs A/QC.96/572 PARA 124b(ii); A/AC.96/588, para 17.(Prior to this, strong suggestions had been made that a duty be imposed on the flag State of the rescuing vessel to provide resettlement places for the rescued refugees and displaced persons and several States agreed in principle to this suggestion, D. WILLDAY, op.cit. supra note 45 at p. 9). Places from the fund have been used for emergencies, in consultation with the resettlement country and with its consent. The schemes of resettlement provided in cases of rescue at sea will now be affected (and will in all probability cease) as a consequence of the agreement on screening procedures reached at the June 1989 Geneva international conference. See, e.g., statement by the Australian delegation at the International Conference on Indo-Chinese Refugees, mimeo, Geneva, 13 June 1989, at p.8. At the Informal Meeting of the Steering Committee of the International Conference on Indo-Chinese refugees held in Manila, 17-18 May 1990, several delegations observed that rescue cases should continue to be handles on an ad hoc basis as, in the absence of a resolution of the problem of non-refugees, consensus was not possible (Report, p.3).

47. UN Doc. A/34/627, p.7.

48. The monthly rate of departures for permanent resettlement abroad from the entire area reached 25,000 in September and October 1979. UNHCR Doc. 155/30/80 Rev. 1, p.9. Between the end of July 1979 and 30 August 1980, 269,111 Indo-Chinese were moved to over thirty resettlement countries. UN Doc. A/AC. $96 / 580$ p.2. This high rate "continued into 1980 , reaching a record of 19,924 in February and averaging 24,419 over the first six months... including those travelling to Refugee Processing Centres", UN Doc. A/AC.95/580 p.4. Since that time, however, this particular situation has worsened again and in recent years boat people have been leaving Vietnam in record numbers (the 1988 arrivals by boat were more than double the 1986 figure (D. MCNAMARA, Deputy Director of Division of Refugee Doctrine, UNHCR, Geneva, "With goodwill, the UN Plan can save lives", International Herald Tribune, June 30, 1989, p.4) and in the last 3 days of May 1989 more than 2,300 boat people arrived in Hong Kong alone (Inhumane Deterrence: The Treatment of Vietnamese Boat People in Hong Kong, (Lawyers Committee for Human Rights, New York, 1989), p.7. The total arrivals in Hong Rong for 1989 were the highest ever $-34,116$ (UNHCR statistics). 
Another application of the dual concepts of temporary refuge and international burden-sharing can be seen in the establishment of holding centres to which refugees and displaced persons can be transferred for processing "for resettlement in an orderly way within a specific time scale, and against guarantees that there would be no residual problem". 49 These developments followed from a suggestion, first made in $19788^{50}$ designed to alleviate the concerns of countries of first asylum that grants of temporary asylum might lead to long-term problems for the country providing this refuge. The idea was that refugees and displaced persons granted resettlement opportunities by third countries, would be taken from the country of first refuge to the processing centres, and, after completion of the formalities prerequisite to admission by their new countries, would then proceed to take up the resettlement offers. Indonesia and the Philippines have provided territory for this purpose, ${ }^{51}$ and camps were constructed for 10,000 persons on Galang Island on the Riau Archipelago near Singapore, and the 50,000 persons on the Bataan Peninsula in the Philippines. At the 1989 UN convened Geneva meeting proposals were made for the establishment of further holding centres: both for those determined, after screening, to be refugees pending their resettlement; and, for those determined not to have refugee status, pending their return to their country of origin. ${ }^{52}$

Yet another example of international cooperation and burden-sharing is the Orderly Departure Programme from Vietnam. In the Declaration and Comprehensive Plan of Action adopted at the 1989 Geneva international conference on Indo-Chinese refugees the regular departure programmes from Vietnam were seen "to offer a preferable alternative to clandestine departures" and it was resolved that these "should be fully encouraged and promoted". ${ }^{53}$

The Australian experience will be outlined as one example of the Orderly Departure Programme's implementation over the past few years. ${ }^{54}$ In March 1982, the Australian and Vietnamese government signed a Memorandum of Understanding. Under the agreed scheme people are brought from Vietnam through a flexible application of the Australian fam-

49. UN Doc. A/34/627 p.8.

50. Made first at the Consultative Meeting with Interested Governments on Refugees and Displaced Persons in S.E. Asia, held at Ceneva on 11 and 12 December 1978.

51. UN Doc. A/34/627 p.9.

52. See closing statement at June 1989 Geneva international conference, UN Doc. A/Conf. 148/ 5 p.3. Progress on the proposed new resettlement centre in the Philippines was reported at the May 1990 informal meeting in Manila.

53. UN Doc. A/Conf $148 / 2$ para 2.

54. In Australia this programme is now called the Family Reunion Programme for Vietnam. 
ily reunion migration policy. This has been regarded strictly as a migration programme, but it has the underlying purpose of providing an alternative to departure by boat, at least for those people who have relatives who qualify to sponsor them. The first migrant under this scheme arrived in November 1982.

Sponsors in Australia who wish to bring in relatives from Vietnam apply to their local regional Department of Immigration office, which examines the level of support which will be provided towards the settlement of the potential migrant. There are delays and backlogs with the applications, and priorities have been developed. Once checked by the regional office, the application is sent to the central office in Canberra where lists are prepared of names to be presented to the Vietnamese government for it to approve departure. The initial list of 6,000 names was handed over in June $1982 .{ }^{55}$ The number of applications has increased tremendously, as a consequence of the large numbers of refugees from Vietnam (over 100,000) who have arrived for resettlement in Australia and who wish to sponsor their relatives.

In 1984-85, 2,699 Vietnamese people received visas under the arrangements, and approximately 3,500 were expected in $1985-86$, but only 2,456 migrant visas were issued in Hanoi. This was due to difficulties within Vietnam. Since then the Australian government has acted to improve the operation of the programme by relocating the processing office to Bangkok, by clearing the backlog of Australian interest cases, and by improving the medical processing system. ${ }^{56}$

At the May 1990 informal meeting of the Steering Committee of the International Conference on Indo-Chinese Refugees held in Manila, the measures recently taken by the government of Vietnam to reduce clandestine departures were reported, as were discussions by UNHCR, UNDP and the ILO as to further appropriate measures. Although there is no room for complacency, ODP departures have increased and clandestine departures, particularly to Hong Kong have declined. ${ }^{57}$

From examples such as these it is possible to argue that, albeit haltingly, and from time to time undisputedly beset with difficulties, concepts of temporary refuge, coupled with ideas of an evolving responsibility of international cooperation, may be in the course of being accepted as customary principles of international refugee law. If this is so, these principles will bind all nations, regardless of whether or not they are parties to

55. DIEA (Dept. of Immigration) Review 1982, Canberra, pp.56-67.

56. Mr. C. HURFORD, then Minister for Immigration, in Department of Foreign Affairs Backgrounder, No. 515 (12.3.86), p.111. The number of persons issued visas for migrant entry in Hanol for $1985-86$ were 2,456 and from July-December 1986 were 1,447 .

57. Report of Meeting at p.2. 
any conventions whereby they specifically accept obligations in relation to refugees.

Today, however, it might be thought that the acceptance of these principles, as principles of customary international law, is under very real threat indeed. Countries of first asylum have been stretched to their utmost limit and, in addition, "compassion fatigue" is clearly evident in States which formerly had been ready to make available resettlement opportunities. It is argued here that reliance on the concepts of temporary refuge, access to fair determination procedures for all, and international burden-sharing have not been destroyed thereby. The consequence of course has been the crisis situation now reached in Hong Kong and in other South-East Asian States and, as indicated earlier, at the two international conferences convened in 1989 to discuss solutions to this crisis. The approach taken by several States was that the only way a solution could work would be through the forcible repatriation of all those determined not to have refugee status ${ }^{58}$ during the new screening processes which the participating States agreed would be established. Furthermore, this approach has continued at later meetings (for example at the Third Meeting of the Steering Committee of the International Conference in Indo-Chinese Refugees held in Geneva in January 1990, and at the later informal meeting of that Committee held in Manila in May $19900^{59}$

Of course, unless the screening procedures in question are fairly and properly administered and applied ${ }^{60}$ the implementation of repatriation as a solution clearly will be very serious indeed. In an endeavour to ensure that the procedures and the criteria of the Convention definition

58. See statements made at the conference by the representatives of the Australian and the United Kingdom governments: statement by the Australian delegation, (mimeo) 13 June 1989, Geneva, pp.3, 5, 6; Speech by British Secretary of State for Foreign and Commonwealth Affairs, (mimeo) Geneva, 13 June 1989, paras 14, 16, 20. Regarding repatriation, D. McNAMARA has stated: "The most misunderstood provision of the plan may be the possible repatriation of those found not to be refugees. The plan provides that such persons should return to their country of origin', and that every effort should be made to encourage this on a voluntary basis. If this fails alternatives 'recognised as being acceptable under international practices' are to be examined. Illegal immigrants are returned home regularly from Western and other countries without any international outcry. To suggest that to do so is a violation of basic refuge rights is clearly a distortion". Loc.cit. at n. 48, p.4.

59. See UNHCR report of Third Meeting, and statement by Countries of Temporary Refugee submitted to informal meeting, p.2.

60. Of the screening procedures it has been said: "This has happened at a time when the number of asylum-seekers has...soared, and the risks are also increasing. Over 100 Vietnamese were murdered in one terrifying pirate attack. Another 100 drowned on June 6 when their boat broke up off the Philippines. Screening cannot be undertaken lightly in such a context. Here are people who were prepared to risk arrest in Vietnam, mutilation and murder by pirates, drowning at sea, indefinite detention in rat-infested camps, and racism in a new home. To ask whether they have a 'well founded fear of persecution' as the screeners will do, seems almost indecent. Certainly, to be credible screening will have to be fair and consistently applied, with the UNHCR taking the lead. At present, none of this applies." I. GUEST, The Angument Against... (Geneva, 30 June 1989, p.2.) 
would be properly understood and administered beginning in mid-1989 the UNHCR undertook an extensive training programme. The consequence hopefully will be that the screening is indeed conducted in a fair and equitable manner (and it goes without saying that this is absolutely essential) and that the Convention definition criteria will be fairly and accurately applied - and this has to be assumed to be the aim of the States reaching agreement on the comprehensive plan of action. If this is so, then despite what may have appeared to be serious backtracking, the notions of temporary refuge and international burden-sharing still do remain the solutions envisaged ${ }^{61}$ Despite the fact that some of the statements made during, and the outcome of, the 1989 Kuala Lumpur and Geneva conferences and the 1990 Geneva Conference were far from encouraging, nonetheless, in relation to the points of developing customary international law under discussion here the situation remains that, for those persons determined to be Convention refugees the concept of temporary refuge and international burden-sharing in the form inter alia of the provision of resettlement opportunities by third countries, ${ }^{62}$ (and, for all asylum-seekers, the concept of temporary refuge and access to status determination procedures ${ }^{63}$ ) continue to be the solutions agreed upon in the comprehensive plan of action drawn up at the first, and adopted at the second, meeting ${ }^{64}$ and re-emphasised at the January 1990 meeting and at the later informal meeting in Manila. ${ }^{65}$ The willingness of first asylum countries to continue to abide by these principles is, however, clearly predicated upon a requirement of real international burden-sharing.

61. "The plan endorsed at the recent Geneva conference on Indo-chinese refugees has been unfairly criticised. It represents the first formal agreement by all governments involved that all Indo-chinese asylum-seekers will be granted temporary refuge or asylum... The plan just adopted is an alternative to harsher bilateral measures. It reaffirms the right to temporary refuge. If respected, lives will be saved...governments have agreed to provide guaranteed resettlement for refugees in camps in the region." D. MCNAMARA, loc.cit. at n.48, p.4. For a view, however, as to the likely scenario if fairly administered and applied screening procedures do not eventuate, see I. GUEST, loc.cit, at no.60, pp.1,2: "If the UNHCR fails to deliver it could find itself bullied into endorsing the forcible repatriation of boat people back to Vietnam. This would be unthinkable for an agency that was set up to protect refugees ... governments appear to view screening as a way of deterring rather than identifying refugees. This clearly has to change before those who are 'screened out' can be sent back to Vietnam ... It could prove hard for the UNHCR to turn its back on the unfortunate returnees if it considers they have been unfairly screened. The UNHCR has tacitly admitted as much by agreeing to 'monitor' their re-integration into Vietnam. This comes perilously close to endorsing forcible repatriation. Right now, the plan may look like a brave attempt to buy time, the only alternative to push-offs, and the best bay of protecting the boat people. In addition, the prospect of 'solving' the seemingly endless crisis of Vietnam's refugees is deeply appealing. This is mistaken. Once the UNHCR endorses deterrence and forcible repatriation it weakens, not strengthens, protection for all the 14 million refugees currently under its care. At some point this agency will have to have the courage to stand up to governments and say no." 


\section{CONCLUDING COMMENTS}

One thing appears to be clear - in order to be at all effective the attempt to solve the world relugee problem must be made at the level of international cooperation. Piecemeal measures are simply not enough. "No single action, however generous, will suffice, the crisis demands coherent and closely coordinated action of the international community if further lives are not to be lost." 66

In the wider world context there has grown an appreciation of the problems, hostilities, conflicts and wars which the human race seems incapable of avoiding in its present system of nation States, and attempts have been made to establish a community of international dimension. The creation of such bodies as the League of Nations, the United Nations, and regional organisations of States, though far from a total solution, has provided arenas which, used wisely, can facilitate discussion, joint undertaking of projects, growth of common interests, and awareness of, and appreciation for, different viewpoints, ideologies, cultures, traditions and economic and political systems and problems. Hopefully, from such

62. UN Doc. A/Conf. 148/2, paras 8,9, 10,11: "Continued resettlement of Vietnamese refugees benefitting from temporary refuge in South-East Asia is a vital component of the Comprehensive Plan of Action... The Long-Stayers Resettlement Programme includes all individuals who arrived in temporary asylum camps prior to the appropriate cut-off date and would contain the following elements: (a) A call to the international community to respond to the need for resettlement, in particular through the participation by an expanded number of countries beyond those few currently active in refugee resettlement and (b) a multi-year commitment to resettle all the Vietnamese who have arrived in temporary asylum camps prior to an agreed date, except those persons already found not to be refugees under established status-determination procedures and those who express the wish to return to Vietnam. The resettlement Programme for Newly-determined Refugees will accommodate all those who arrive after the introduction of status-determination procedures and are determined to be refugees. Within a designated period after their transfer to the resettlement area, those determined to be refugees shall receive an orientation briefing from a UNHCR representative that explains the third-country resettlement programme, the length of time current arrivals may be expected to spend in camp awaiting resettlement, and the necessity of adhering to the rules and regulations of the camp. Wherever possible, a pledge shall be sought from the resettlement countries to place all those determined to be refugees, except those expressing the wish to return to Vietnam, within a prescribed period. It shall be the responsibility of UNHCR, with the full support of all the resettlement countries and countries of asylum, to coordinate efforts to ensure that departures are effected within that time."

63. Ibid, para 5: "All those seeking asylum will be given the opportunity to do so through the implementation of the following measures: (a) Temporary refuge will be given to all asylumseekers, who will be treated identically regardless of their mode of arrival until the statusdetermination process is completed. (b) UNHCR will be given full and early access to new arrivals and will retain access, following the determination of their status. (c) New arrivals will be transferred, as soon as possible, to a temporary asylum centre where they would be provided assistance and full access to the refugee status-determination process."

64. See paras 5,8,9,10,11. (and 16,17 regarding resettlement of Laotian refugees) of the Draft Declaration and Comprehensive Plan of Action approved at the Kuala Lumpur meeting and adopted at the Ceneva meeting, UN Doc. A/Conf. 148/2. The concern here is, of course, that the definition criteria will be applied inaccurately and restrictively and that Convention refugees may be forcibly repatriated as a consequence. 
beginnings should spring a greater opportunity for international cooperation and a lesser likelihood of confrontation - and in view of the recent changes in Eastern Europe and the improvement of relations between the two superpowers there is increased optimism that those international structures will become increasingly able to achieve their aims.

In relation to the refugee problem, itself, the move has been from ad hoc national responses, and ad hoc responses to the problems of specific categories of refugees, to an emphasis on the need for an international assumption of responsibility and action.

Not all the examples of this trend have been covered in this paper but instances are: the drawing up of an international convention defining the legal status, rights and duties of refugees and the giving to the term "refugee $^{n}$ some kind of general definition; accession to this Convention (and/ or its Protocol) by more than 100 nations; the establishment of an international body to protect, assist and find permanent solutions to the problems of refugees, the repeated extensions which have been made to this body's mandate, the cooperation it receives from the governments of States parties to the 1951 Convention or the 1967 Protocol, and from other governments also, as well as that of many other organisations all over the world; the drafting and adopting of many other international and regional instruments relating directly and indirectly to the welfare of refugees; the development of some relevant rules of customary international law which bind all nations regardless of their accession to specific treaties; the increasing recognition of the need for the promotion of humanitarian principles and the concepts of equity and burden-sharing amongst nations and the emphasis which these concepts have received both at recent international meetings and in recent instruments; the solutions advocated for the particular problems of boat refugees and the measures taken to improve their chances of rescue at sea. All these instances exhibit a concern to tackle the refugee problem at an international level and not to leave it in the lap of the States in the area of immediate geographical proximity.

These steps are encouraging and undoubtedly over the last seventy years or so significant progress has been made in the approach to the problems of refugees. But is progress of this type sufficient, or, in a wider

65. In the general statements of delegates reported from the Informal Meeting of the Steering Committee of the International Conference on Indo-Chinese Refugees held in Manila in May 1990 the need to resolve the problems of those determined not to be refugees and for further efforts to reach consensus on their return in safety and dignity received emphasis, but it was also stressed that abandonment of first asylum could not be justified (see 2 and 3 of the report).

66. UN Doc. A/34/627 Annex 1, p.7. 
context, is it a mere token gesture in a world bent on destruction? As Arthur Koestler has commented,

"the most striking indication of the pathology of our species is the contrast between its unique technological achievements and its equally unique incompetence in the conduct of its social affairs. We can control the motions of satellites orbiting distant planets, but cannot control the situation in Northern Ireland. ${ }^{.67}$

There could be added to these examples man's incompetence so far to deal with the narrow ideologies and human cruelty which cause people to become refugees.

The same author goes on to note:

"For the vast majority of mankind throughout history, the system of beliefs which they accepted, for which they were prepared to live and to die, was not of their own making or choice; it was shoved down their throats by the hazards of birth. Pro patria mori dulce et decorum est, whichever the patria into which the stork happens to drop you. Critical reasoning played, if any, only a secondary part in the process of adopting a faith, a code of ethics...; of becoming a fervent Christian crusader, a fervent Moslem engages in Holy War...The continuous disasters in man's history are mainly due to his excessive capacity and urge to become identified with a tribe, nation, church or cause, and to espouse its credo uncritically and enthusiastically, even if its tenets are contrary to reason, devoid of self-interest and detrimental to the claims of self-preservation."68

From such a base we have created refugees, people who have a "wellfounded fear of being persecuted for reasons of race, religion, nationality, membership of a particular social group of political opinion ${ }^{n 69}$ and others "in refugee-like circumstances" to whom we may not be prepared to afford protection.

A world spirit of cooperation, awareness, and identification with humanity in general, as opposed to a small fraction of it, seems an essential first step to the resolution of the immense problems we have brought about by our preoccupation with, and fanatical belief in, the exclusive rightness and superiority of our own little corner of the earth, wherever and whatever that may be.

The changing response to the refugee problem, having moved as it has over the last half century from ad hoc local and national assistance, to an emphasis on the need for an assumption of responsibility and cooperation at an increasingly wide international level, does provide a glimmer of

67. A. KoESTLER, Janus: A Summing Up (Hutchinson, Australia, 1978), p.3.

68. Ibid, at p.14.

69. Art. 1(A)/2), 1951 Convention. 
hope that here at least we may finally be moving in the right direction. Nonetheless, the lack for many refugee status applicants of full and early access to determination procedures, the 1988 turning away of Vietnamese from the shores of Thailand, the 1989 push-offs of thousands of Vietnamese from the Malaysian coast, pirate attacks in 1989 almost double the number of those of $1988,{ }^{70}$ the lack of adequate assistant to Burmese sheltering on the Thai border, the detention of asylum seekers in many countries in camps with less than the minimum acceptable standards, the closed camps in Hong Kong, and the threats of forcible repatriation to Vietnam coupled with screening mechanisms which may result in a denial of refugee status to genuine claimants - all these are stark reminders that there is absolutely no room for complacency.

70. UNHCR statistics for 1989 were almost double those of 1988 and pirates more and more try to ensure they leave no witnesses - this may be due to the increasingly sophisticated investigation techniques and higher rates of arrest and conviction. See C. RoBINSON, Testimony on the US, the CPA and Refugee Protection Problems in S.E. Asia, before the Senate Appropriations Committee, US Committee for Refugees, Washington, 1990, pp. 9-10. 